\title{
Pertumbuhan dan Hasil Ratun Tiga Ekotipe Padi berdasarkan Tinggi Pemotongan Berbeda
}

\section{Ratoon Growth and Yield of Three Rice Ecotypes from Different Cutting Height}

\author{
Aptika Hana Prastiwi Nareswari ${ }^{1}$, Eko Sulistyono ${ }^{2 *}$, dan Edi Santosa ${ }^{2}$ \\ 'Program Studi Agronomi dan Hortikultura, Sekolah Pascasarjana, Institut Pertanian Bogor \\ ${ }^{2}$ Departemen Agronomi dan Hortikultura, Fakultas Pertanian, Institut Pertanian Bogor \\ (IPB University), Jl. Meranti, Kampus IPB Darmaga, Bogor 16680, Indonesia
}

Diterima 11 Desember 2020/Disetujui 22 April 2021

\begin{abstract}
Rice ratoon is the practice of obtaining a second harvest from the previously harvested main crop's tillers with a cultivation process that not only efficient in cost and time but also provides extra yield to the main crop. The research aimed to access the growth and yield of three rice ecotypes (lowland, upland and swamps) from different cutting heights. The experiment was carried out at the Babakan Experimental Station, IPB University during September-December 2019 using two factors of RCBD with three replications. The first factor was three ecotypes of rice, namey lowland rice (IPB 3S, Inpari 30), upland rice (Inpago 9, Inpago 10) and swamp rice (Inpara 8, Inpara 9), and the second factor was cutting height to stimulate ratoon growth $(10,20,30$, and $40 \mathrm{~cm})$ from ground level. The results showed that IPB $3 S$ and Inpago 9 with $20 \mathrm{~cm}$ height of cutting yielded a higher number of tillers. Productive tillers had a significant correlation with ratoon yield. It was concluded that cutting height on lowland rice (IPB 3S) of $30 \mathrm{~cm}$ and swamp rice (Inpara 8) of $20 \mathrm{~cm}$ produced the highest rice yield. Path analysis showed that number of grains directly affected ratoon yield.
\end{abstract}

Keywords: cutting height, node bud, path analysis

\section{ABSTRAK}

Padi ratun adalah tanaman padi yang tumbuh dari tunas yang terdapat di buku tunggul atau batang padi tersisa setelah panen. Proses budidaya padi ratun hemat biaya dan waktu dengan memberikan tambahan hasil terhadap tanaman utama. Penelitian bertujuan untuk mengkaji pertumbuhan dan hasil ratun dari tiga ekotipe padi (sawah, gogo, dan rawa) dari tinggi pemotongan batang berbeda. Percobaan dilakukan di Kebun Percobaan Sawah Baru, Institut Pertanian Bogor pada September-Desember 2019 menggunakan rancangan acak kelompok (RAK) dua faktor dengan tiga ulangan. Tiga ekotipe padi yaitu padi sawah (IPB 3S, Inpari 30), padi gogo (Inpago 9, Inpago 10) dan padi rawa (Inpara 8, Inpara 9) ditanam dengan budidaya padi sawah kemudian diratun pada empat ketinggian (10,20,30, dan $40 \mathrm{~cm})$ dari permukaan tanah untuk menstimulir ratun. Hasil menunjukkan bahwa anakan ratun terbanyak dari IPB $3 S$ dan Inpago 9 dihasilkan dengan tinggi potongan $20 \mathrm{~cm}$. Anakan produktif berkorelasi secara signifikan terhadap hasil ratun dalam GKG. Hasil tertinggi ratun dapat diperoleh dari padi sawah (IPB 3S) dengan ketinggian $30 \mathrm{~cm}$ dan padi rawa (Inpara 8) dengan ketinggian $20 \mathrm{~cm}$. Sidik lintas menunjukkan jumlah gabah per malai adalah karakter yang berpengaruh langsung terhadap hasil ratun.

Kata kunci: buku tunas, sidik lintas, tinggi tunggul padi

\section{PENDAHULUAN}

Sebagian besar produksi padi masih didominasi dari hasil sawah irigasi (He et al., 2018). Peningkatan produksi padi menjadi hal yang harus diupayakan. Menurut Ruminta (2016), keberhasilan produksi padi di Indonesia utamanya ditopang oleh peningkatan luas area dan kondisi iklim pada

\footnotetext{
* Penulis untuk korespondensi. e-mail: pengelolaanair@yahoo. com
}

lokasi penanaman. Dariah dan Heryani (2014) menyatakan peningkatan luas area padi sawah di Indonesia menghadapi tantangan berat karena keterbatasan lahan sehingga perlu adanya strategi dalam rangka meningkatkan produksi padi melalui tanaman ratun.

Padi ratun adalah tanaman padi yang tumbuh dari tunas di buku (node) tunggul atau batang padi tersisa pada saat panen (Harrel et al., 2009). Tunggul tanaman padi ini dikenal dengan istilah ratun atau singgang (Jawa) dan turiang (Sunda) yang dapat menambah hasil padi hanya dengan memberikan input minimal (Bond dan Bolich, 2006; 
Chen et al., 2018; Lin, 2019). Tanaman ratun memiliki umur panen yang lebih pendek dibandingkan tanaman utama dengan umur rata-rata 68 hari (Susilawati et al., 2010). Fase ratun yang lebih pendek disebabkan oleh munculnya anakan ratun bersamaan dengan keluarnya malai. Umur berbunga dan umur panen ratun sangat cepat pada tinggi potongan 20$50 \mathrm{~cm}$ di atas permukaan tanah (Mareza et al., 2016). Tinggi potongan juga dapat mempengaruhi jumlah anakan dan hasil biji dari padi ratun (De Datta dan Bernasor, 1988). Semakin tinggi potongan batang yang diaplikasikan pada tunggul diharapkan setiap bukunya dapat memunculkan tunas atau anakan ratun sehingga anakan ratun semakin banyak.

Keberhasilan ratun dipengaruhi oleh varietas, teknologi pemupukan pada tanaman sebelumnya dan ketersediaan air. Tidak semua varietas padi yang ditanam mampu menghasilkan ratun yang dapat tumbuh dan berproduksi dengan baik (Islam et al., 2008; Susilawati, 2011; Sinaga et al., 2015). Penelitian tentang pertumbuhan dan hasil padi ratun yang telah dilakukan di Indonesia memberikan informasi bahwa perlakuan tinggi potongan dapat meningkatkan jumlah gabah isi, mempercepat pertumbuhan ratun dan meningkatkan vigor serta keseragaman ratun varietas Cimelati, Hipa-5 dan Rokan (Susilawati et al., 2012). Berdasarkan varietas yang menurut deskripsinya dapat tumbuh baik pada kondisi sawah, gogo dan rawa serta memiliki karakter morfologi daun yang tegak sesuai kriteria ratun dan mampu berproduksi tinggi, maka dipilih varietas padi sawah (IPB 3S, Inpari 30), padi gogo (Inpago 9, Inpago 10) dan padi rawa (Inpara 8, Inpara 9) untuk diratun dengan teknik budi daya padi sawah. Tujuan penelitian adalah untuk mengkaji pertumbuhan dan hasil ratun dari tiga kelompok ekotipe padi (sawah, gogo dan rawa) dari tinggi pemotongan batang yang berbeda.

\section{BAHAN DAN METODE}

Penelitian dilaksanakan di Kebun Percobaan Sawah Baru, Institut Pertanian Bogor pada September-Desember 2019 dengan curah hujan bulanan berkisar $301.32 \mathrm{~mm}$ per bulan pada September, $21.92 \mathrm{~mm}$ per bulan pada Oktober, $1520.86 \mathrm{~mm}$ per bulan pada November dan $21.92 \mathrm{~mm}$ per bulan pada Desember 2019. Hasil analisis tanah bahwa lokasi penelitian memiliki $\mathrm{pH} 6.21$ dengan kadar hara $0.54 \% \mathrm{~N}$ (tinggi), $48.98 \mathrm{ppm} \mathrm{P}$ (tinggi) dan $0.18 \mathrm{cmol} \mathrm{kg}^{-1}$ $\mathrm{K}$ (rendah) untuk penanaman padi secara irigasi.

Penelitian menggunakan rancangan acak kelompok (RAK) dua faktor. Tiga kelompok padi yaitu padi sawah (IPB 3S, Inpari 30), padi gogo (Inpago 9, Inpago 10) dan padi rawa (Inpara 8, Inpara 9) dipotong pada empat ketinggian $(10,20,30$, dan $40 \mathrm{~cm})$ dari permukaan tanah untuk menstimulir ratun. Masing-masing perlakuan diulang sebanyak tiga kali. Irigasi diberikan dengan tinggi genangan $2.5 \mathrm{~cm}$ satu minggu sebelum tanaman utama dipotong sesuai ketinggian. Pemupukan ratun diberikan pada satu minggu setelah pemotongan batang tanaman utama sebesar $100 \mathrm{~kg}$ urea ha ${ }^{-1}, 100 \mathrm{~kg} \mathrm{SP}-36 \mathrm{ha}^{-1}$ dan $50 \mathrm{~kg} \mathrm{KCl} \mathrm{ha}^{-1}$ atau setara dengan setengah dari dosis pupuk tanaman utama (Susilawati et al., 2012).
Tanaman utama dari tiga kelompok ekotipe padi (sawah, gogo dan rawa) ditanam menggunakan perlakuan pengaturan tinggi muka air $(0,-5,-10$, dan $-15 \mathrm{~cm})$ sampai fase pemasakan dan dibudidayakan pada bulan AprilSeptember 2019. Pemupukan tanaman utama telah dilakukan sebanyak tiga kali dengan dosis $200 \mathrm{~kg} \mathrm{ha}^{-1}$ urea, $200 \mathrm{~kg}$ $\mathrm{ha}^{-1} \mathrm{SP}-36$ dan $100 \mathrm{~kg} \mathrm{ha}^{-1} \mathrm{KCl}$. Tanaman ratun dipelihara dengan ketinggian air $2.5 \mathrm{~cm}$.

Pengamatan pertumbuhan ratun diawali dengan menghitung waktu muncul tunas baru dari bekas potongan selama 7 hari setelah pemotongan tanaman utama (HSP), tinggi tunas $(\mathrm{cm})$ diukur dari tempat munculnya tunas hingga ujung tunas, tinggi buku tunas $(\mathrm{cm})$ dari permukaan tanah hingga buku dimana tunas baru muncul. Tinggi tanaman ratun $(\mathrm{cm})$ dari permukaan tanah hingga daun tertinggi diukur setelah $7 \mathrm{HSP}$, panjang dan lebar daun diukur saat fase vegetatif akhir atau saat awal fase berbunga (50\% populasi contoh telah berbunga). Panen dilakukan saat $80 \%$ malai telah menguning pada setiap satuan percobaan kemudian dilakukan pengamatan yaitu anakan produktif, panjang malai $(\mathrm{cm})$, jumlah gabah per malai, persentase gabah isi, bobot 1,000 butir dan gabah kering giling (GKG). GKG dihitung berdasarkan rumus dari BBPTP (2017) yaitu $\mathrm{GKG}=\mathrm{GKP} \times 0.86$

\section{HASIL DAN PEMBAHASAN}

\section{Pertumbuhan Vegetatif Ratun}

Hasil yang ditampilkan pada Tabel 1 menunjukkan bahwa kombinasi perlakuan tinggi potongan $20 \mathrm{~cm}$ dengan varietas Inpago 9 menghasilkan tunas terbanyak dan tidak berbeda dengan varietas IPB $3 \mathrm{~S}$. Tunas atau anakan ratun tersebut muncul akibat adanya suplai karbohidrat ke daerah pertumbuhan yang memicu keluarnya tunas baru. Asimilat yang tersisa pada tunggul dimanfaatkan bagian tanaman yang tersisa untuk pembentukan tunas (Susilawati, 2011). Tunas yang tumbuh pada ratun padi disebut sebagai anakan ratun merupakan fenomena pemutusan dominansi apikal karena memicu pertumbuhan tunas lateral setelah pemotongan batang tanaman utama (Jahari dan Sinaga, 2019). Inisiasi tunas lateral dapat dilakukan untuk meningkatkan jumlah anakan sehingga produksi tanaman dapat bertambah (Khuluq dan Hamida, 2014). Proses pemotongan batang utama saat panen dapat dipermudah dengan menyisakan dua buku dibawah bekas potongan atau $16-30 \mathrm{~cm}$ diatas permukaan tanah. Bekas potongan batang tanaman utama akan memunculkan tunas-tunas lateral yang menghasilkan pertumbuhan vegetatif (Alizadeh et al., 2011; Mareza et al., 2016).

Rata-rata tunas ratun muncul pada hari pertama setelah tanaman utama dipotong. Tunas dari semua varietas yang diratun dari potongan 20,30, dan $40 \mathrm{~cm}$ akan muncul dari bagian tengah tunggul dekat dengan bekas potongan (Tabel 1). Pemotongan batang menyebabkan hilangnya meristem apikal sehingga laju pemanjangan batang menurun dan menginisiasi munculnya tunas lateral mendekati bekas potongan yang kemudian disebut sebagai anakan ratun 
(Ningrum et al., 2018). Pemberian ABA pada tunggul yang telah dipanen diduga dapat meningkatkan regenerasi tunas aksilar sehingga anakan ratun diharapkan dapat muncul pada setiap ruas batang (Azizi et al., 2015; He et al., 2019). Tunas dari potongan $10 \mathrm{~cm}$ memiliki posisi paling dekat dengan tanah sebagai sumber nutrisi. Menurut Susilawati (2011), semakin dekat tunas tersebut dengan tanah sebagai sumber nutrisi, maka anakan ratun yang muncul diharapkan lebih vigor.

Hasil sidik ragam menunjukkan adanya pengaruh interaksi antara tinggi potongan batang dengan varietas padi terhadap tinggi ratun pada umur 4 minggu setelah pemotongan (MSP). Potongan yang semakin tinggi dapat menghasilkan ratun yang tinggi. Kombinasi perlakuan tinggi potongan $40 \mathrm{~cm}$ pada Inpara 8 menghasilkan ratun yang tinggi tetapi tidak berbeda dengan tinggi ratun dari varietas Inpara 9 pada tinggi potongan $30 \mathrm{~cm}$ (Tabel 1). Potongan yang lebih tinggi menyebabkan tunas ratun tumbuh lebih cepat tetapi tidak seragam akibat munculnya tunas bermalai
(Gambar 1). Malai tersebut akan berkembang dan matang lebih cepat namun jumlah gabah yang bernas lebih sedikit karena satu anakan ratun dapat menopang lebih dari satu malai sehingga asimilat yang ditranslokasikan untuk pembentukan dan pengisian biji lebih sedikit dibandingkan pada tanaman utama yang menghasilkan satu malai untuk satu anakan (Xu et al. 2015; Dong et al., 2017; Nuzul et al., 2018).

\section{Komponen Hasil Ratun}

Respon tanaman ratun tidak selalu mengikuti tanaman utama. Rata-rata anakan produktif yang dihasilkan tanaman utama sebanyak 17.64 dengan jumlah gabah per malai mencapai 194.76 butir. Ratun padi yang mampu menghasilkan gabah pada percobaan ini memiliki persen gabah isi cukup rendah antara $0-52 \%$. Anakan produktif yang dihasilkan oleh ratun rata-rata berjumlah 8.87 anakan per rumpun atau $50 \%$ dari tanaman utama (Tabel 2).

Tabel 1. Jumlah tunas, posisi tunas, dan tinggi ratun beberapa varietas padi pada empat perlakuan tinggi ratun

\begin{tabular}{|c|c|c|c|c|}
\hline $\begin{array}{l}\text { Tinggi } \\
\text { potongan }(\mathrm{cm})\end{array}$ & Varietas & $\begin{array}{c}\text { Jumlah } \\
\text { tunas }\end{array}$ & $\begin{array}{l}\text { Posisi tunas* } \\
(\mathrm{cm})\end{array}$ & $\begin{array}{c}\text { Tinggi ratun } \\
(\mathrm{cm})\end{array}$ \\
\hline \multirow[t]{6}{*}{10} & IPB 3S & 7.97abcde & 4.44hij & $62.31 \mathrm{fgh}$ \\
\hline & Inpari 30 & $8.70 \mathrm{abc}$ & $3.77 \mathrm{j}$ & $52.95 \mathrm{klm}$ \\
\hline & Inpago 9 & 7.63abcdef & $3.68 \mathrm{j}$ & $53.03 \mathrm{jklm}$ \\
\hline & Inpago 10 & 4.97defgh & $2.64 j$ & $47.64 \mathrm{~m}$ \\
\hline & Inpara 8 & $3.87 \mathrm{gh}$ & 5.10hij & $60.43 \mathrm{ghi}$ \\
\hline & Inpara 9 & $4.20 \mathrm{gh}$ & 5.36ghij & 58.03hijkl \\
\hline \multirow[t]{6}{*}{20} & IPB 3S & $9.13 \mathrm{ab}$ & 7.88efghi & 63.57efgh \\
\hline & Inpari 30 & 6.03abcdefg & 6.07fghij & $51.421 \mathrm{~m}$ \\
\hline & Inpago 9 & $10.00 \mathrm{a}$ & $9.15 \mathrm{defg}$ & $59.75 \mathrm{ghij}$ \\
\hline & Inpago 10 & 4.83efgh & $3.95 \mathrm{ij}$ & 59.17hijk \\
\hline & Inpara 8 & 6.60abcdefg & $9.08 \mathrm{defg}$ & $63.03 \mathrm{fgh}$ \\
\hline & Inpara 9 & 8.30abcde & $12.50 \mathrm{~cd}$ & $66.13 \mathrm{efg}$ \\
\hline \multirow[t]{6}{*}{30} & IPB 3S & $8.70 \mathrm{abc}$ & $9.47 \mathrm{def}$ & $75.08 \mathrm{abc}$ \\
\hline & Inpari 30 & $4.17 \mathrm{gh}$ & $13.67 \mathrm{c}$ & 55.09ijkl \\
\hline & Inpago 9 & $4.27 \mathrm{gh}$ & 7.79efghi & $67.83 \mathrm{def}$ \\
\hline & Inpago 10 & 6.07bcdefgh & 8.00efgh & $73.43 \mathrm{bcd}$ \\
\hline & Inpara 8 & $5.50 \mathrm{cdefgh}$ & $14.57 \mathrm{c}$ & $67.37 \mathrm{def}$ \\
\hline & Inpara 9 & 7.33abcdefg & $18.65 b$ & $78.30 \mathrm{ab}$ \\
\hline \multirow[t]{6}{*}{40} & IPB 3S & 4.40fgh & $13.96 \mathrm{c}$ & $75.08 \mathrm{abc}$ \\
\hline & Inpari 30 & 7.57abcdef & $13.44 \mathrm{c}$ & $55.09 \mathrm{ijkl}$ \\
\hline & Inpago 9 & 4.57fgh & $22.04 \mathrm{ab}$ & $67.83 \mathrm{def}$ \\
\hline & Inpago 10 & $8.40 \mathrm{abcd}$ & $10.96 \mathrm{cde}$ & $73.43 \mathrm{bcd}$ \\
\hline & Inpara 8 & 6.83abcdefg & $22.56 \mathrm{ab}$ & $67.37 \mathrm{def}$ \\
\hline & Inpara 9 & $2.90 \mathrm{~h}$ & $22.77 \mathrm{a}$ & $78.30 \mathrm{ab}$ \\
\hline
\end{tabular}

Keterangan: Angka yang diikuti huruf yang sama pada kolom yang sama tidak berbeda nyata berdasarkan BNT taraf $\alpha=5 \%$; ${ }^{*}$ posisi tunas pertama dari permukaan tanah 


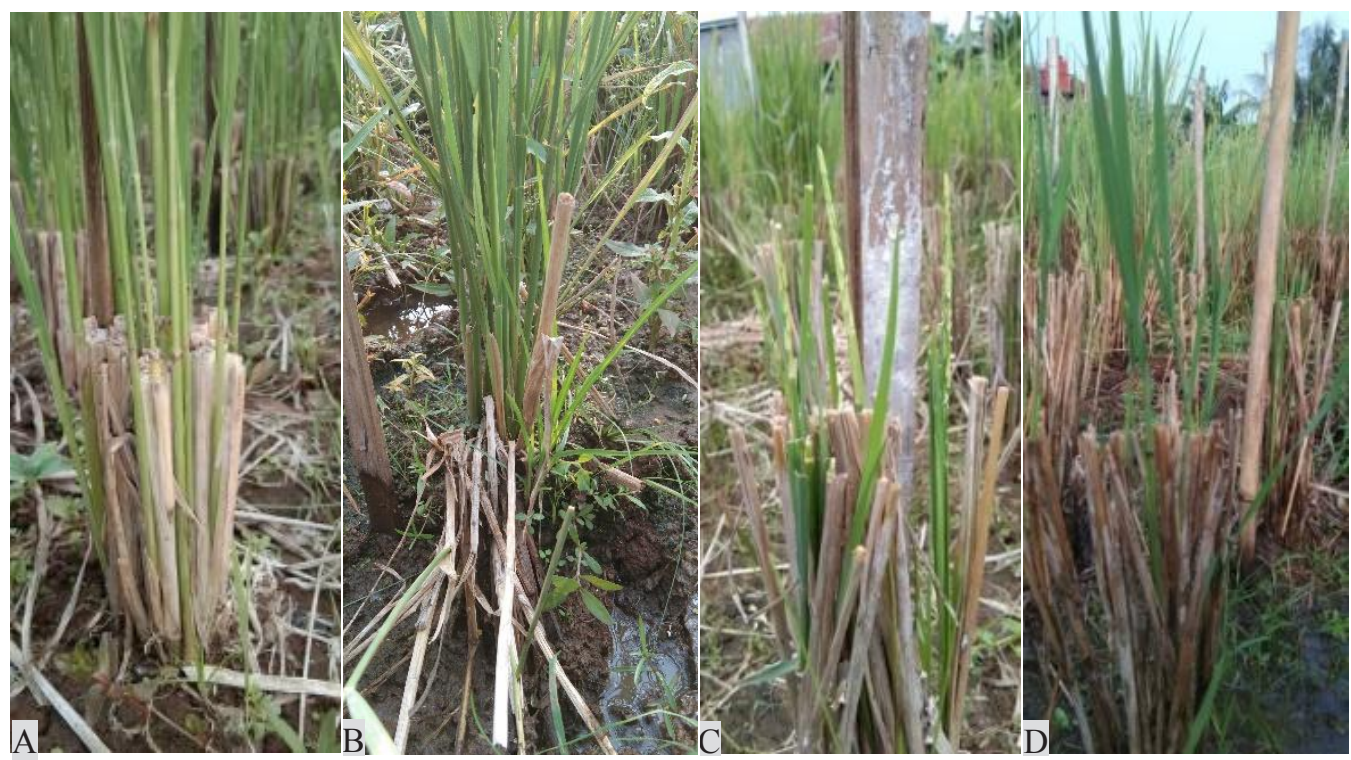

Gambar 1. Tunas pada potongan (A) $10 \mathrm{~cm}$, (B) $20 \mathrm{~cm}$, (C) $30 \mathrm{~cm}$ dan (D) $40 \mathrm{~cm}$

Berdasarkan penelitian Faruq et al. (2014), jumlah anakan produktif maksimal yang dapat dihasilkan oleh ratun padi irigasi adalah 15 anakan setara $62 \%$ dari anakan produktif pada tanaman utama dengan jumlah terendah yaitu 3 anakan.

Ratun dengan tinggi potongan setinggi $40 \mathrm{~cm}$ pada penelitian ini mengalami kematian pada fase generatif. Menurut Susilawati (2011), hal tersebut diduga akibat asimilat yang tersisa pada tunggul tidak dimanfaatkan untuk pembentukan biji. Produksi ratun pada penelitian ini berkisar 52-91\%. Berdasarkan hasil penelitian sebelumnya, hasil ratun akan bervariasi antara $0-91 \%$ dan cenderung mengalami penurunan bahkan tidak berproduksi (Sinaga et al., 2015; Meliala et al., 2017). Rendahnya produksi ratun dapat diatasi dengan meningkatkan jumlah populasi dan dosis pupuk dari tanaman utama (Vinutha et al., 2016). Penurunan

Tabel 2. Anakan produktif dan jumlah gabah per malai tanaman utama beberapa varietas padi

\begin{tabular}{lcc}
\hline Varietas & Anakan produktif & Gabah per malai (butir) \\
\hline IPB 3S & 18.33 & 201.67 \\
Inpari 30 & 17.92 & 207.07 \\
Inpago 9 & 17.80 & 194.37 \\
Inpago 10 & 16.94 & 181.59 \\
Inpara 8 & 16.70 & 205.55 \\
Inpara 9 & 18.17 & 178.29 \\
\hline Rata-rata & 17.64 & 194.67 \\
Pr $>$ F & 0.86 & 0.32 \\
\hline
\end{tabular}

Keterangan: Hasil tidak berbeda nyata berdasarkan uji $\mathrm{F}$ taraf $\alpha$ $=5 \%$ dosis pupuk $\mathrm{N}$ pada tanaman ratun untuk mengurangi konsentrasi asimilat ke bagian pertumbuhan, pemberian $\mathrm{N}$ yang terlalu tinggi akan menekan kemampuan tanaman dalam menyerap unsur lain sehingga memungkinkan terjadinya defisiensi unsur lain. Apabila tanaman tidak mampu menyerap unsur lain seperti $\mathrm{P}$ dan $\mathrm{K}$ maka dapat meningkatkan persentase gabah hampa pada ratun (Liu et al., 2014; Ambarita et al., 2017). Pengeringan tanah selama fase pengisian biji juga dapat dilakukan untuk mengurangi risiko penurunan produksi (Wang et al., 2020). Ratun dari varietas IPB 3S dan Inpara 8 memberikan produksi masingmasing sebesar $84 \%$ dan $91 \%$ terhadap tanaman utama ketika dipotong pada ketinggian $30 \mathrm{~cm}$ dan $20 \mathrm{~cm}$. Mapegau et al. (2018) menyatakan bahwa varietas padi habitat rawa umumnya memiliki sifat ratun yang dibawa secara genetik sehingga diunggulkan dalam budi daya ratun.

Ratun dari Inpara 8 mampu menghasilkan anakan produktif dengan jumlah sama pada tinggi potongan 10, 20, dan $30 \mathrm{~cm}$ (Tabel 3). Kemampuan dalam menghasilkan anakan produktif akan mempengaruhi hasil ratun. Jumlah anakan produktif, panjang malai dan jumlah gabah per malai berkorelasi secara signifikan dengan hasil gabah kering giling dalam penelitian ini sejalan dengan pernyataan Sadeghi (2011).

Apabila karakter-karakter yang berkorelasi dengan hasil ratun pada Tabel 4 dianalisis menggunakan sidik lintas, maka diketahui bahwa jumlah gabah per malai (1.37) merupakan karakter yang memberikan pengaruh langsung terbesar terhadap GKG ratun (Gambar 2). Sidik lintas padi ratun dapat dianggap sama dengan sidik lintas padi secara umum karena jumlah anakan dan jumlah gabah per malai merupakan karakter dengan pengaruh langsung terbesar terhadap hasil (Bakhtiar et al., 2010; Rachmawati et al., 2014). 
Tabel 3. Hasil padi ratun beberapa varietas padi pada tiga perlakuan tinggi ratun

\begin{tabular}{llccccc}
\hline $\begin{array}{l}\text { Tinggi } \\
\text { potongan }(\mathrm{cm})\end{array}$ & Varietas & $\begin{array}{c}\text { Anakan } \\
\text { produktif }\end{array}$ & $\begin{array}{c}\text { Panjang malai } \\
(\mathrm{cm})\end{array}$ & $\begin{array}{c}\text { Jumlah gabah } \\
\text { per malai }\end{array}$ & $\begin{array}{c}\text { Gabah isi } \\
(\%)\end{array}$ & $\begin{array}{c}\text { Bobot } 1,000 \\
\text { butir }(\mathrm{g})\end{array}$ \\
\hline 10 & IPB 3S & $12.00 \mathrm{bc}$ & $16.90 \mathrm{de}$ & $49.30 \mathrm{de}$ & $23.50 \mathrm{c}$ & $80.86 \mathrm{a}$ \\
& Inpari 30 & $17.30 \mathrm{a}$ & $14.10 \mathrm{~g}$ & $34.30 \mathrm{gh}$ & $47.40 \mathrm{a}$ & $30.22 \mathrm{e}$ \\
& Inpago 9 & $7.00 \mathrm{de}$ & $17.50 \mathrm{~d}$ & $49.50 \mathrm{de}$ & $48.90 \mathrm{a}$ & $66.00 \mathrm{~b}$ \\
& Inpago 10 & $0.00 \mathrm{f}$ & $0.00 \mathrm{~h}$ & $0.00 \mathrm{i}$ & $0.00 \mathrm{f}$ & $0.00 \mathrm{j}$ \\
& Inpara 8 & $13.67 \mathrm{ab}$ & $16.20 \mathrm{ef}$ & $48.70 \mathrm{de}$ & $48.20 \mathrm{a}$ & $44.28 \mathrm{~d}$ \\
& Inpara 9 & $6.00 \mathrm{e}$ & $20.03 \mathrm{~b}$ & $55.10 \mathrm{~d}$ & $51.70 \mathrm{a}$ & $49.02 \mathrm{c}$ \\
& IPB 3S & $9.00 \mathrm{cde}$ & $15.97 \mathrm{f}$ & $39.33 \mathrm{fg}$ & $0.00 \mathrm{f}$ & $0.00 \mathrm{j}$ \\
& Inpari 30 & $0.00 \mathrm{f}$ & $0.00 \mathrm{~h}$ & $0.00 \mathrm{i}$ & $0.00 \mathrm{f}$ & $0.00 \mathrm{j}$ \\
& Inpago 9 & $5.67 \mathrm{e}$ & $19.94 \mathrm{~b}$ & $64.03 \mathrm{c}$ & $18.05 \mathrm{~cd}$ & $20.29 \mathrm{gh}$ \\
& Inpago 10 & $0.00 \mathrm{f}$ & $0.00 \mathrm{~h}$ & $0.00 \mathrm{i}$ & $0.00 \mathrm{f}$ & $0.00 \mathrm{j}$ \\
& Inpara 8 & $13.00 \mathrm{abc}$ & $17.72 \mathrm{~cd}$ & $64.72 \mathrm{c}$ & $15.94 \mathrm{~cd}$ & $17.51 \mathrm{gh}$ \\
& Inpara 9 & $14.00 \mathrm{ab}$ & $23.83 \mathrm{a}$ & $76.67 \mathrm{~b}$ & $17.57 \mathrm{~cd}$ & $18.60 \mathrm{fgh}$ \\
& IPB 3S & $11.00 \mathrm{bcd}$ & $20.76 \mathrm{~b}$ & $86.33 \mathrm{a}$ & $47.73 \mathrm{a}$ & $18.81 \mathrm{fgh}$ \\
& Inpari 30 & $13.00 \mathrm{abc}$ & $14.62 \mathrm{~g}$ & $30.00 \mathrm{~h}$ & $36.46 \mathrm{~b}$ & $15.93 \mathrm{~h}$ \\
& Inpago 9 & $11.00 \mathrm{bcd}$ & $15.85 \mathrm{f}$ & $45.67 \mathrm{ef}$ & $37.94 \mathrm{~b}$ & $17.30 \mathrm{gh}$ \\
& Inpago 10 & $14.00 \mathrm{ab}$ & $18.57 \mathrm{c}$ & $52.33 \mathrm{de}$ & $12.10 \mathrm{de}$ & $6.32 \mathrm{i}$ \\
& Inpara 8 & $13.00 \mathrm{abc}$ & $16.02 \mathrm{ef}$ & $36.67 \mathrm{gh}$ & $5.34 \mathrm{ef}$ & $21.67 \mathrm{f}$ \\
Inpara 9 & $0.00 \mathrm{f}$ & $0.00 \mathrm{~h}$ & $0.00 \mathrm{i}$ & $0.00 \mathrm{f}$ & $0.00 \mathrm{j}$ \\
\hline
\end{tabular}

Keterangan: Angka yang diikuti huruf yang sama pada kolom yang sama tidak berbeda nyata berdasarkan BNT taraf $\alpha=$ $5 \%$

Tabel 4. Koefisien korelasi karakter vegetatif dan komponen hasil padi ratun beberapa varietas padi dengan perlakuan tinggi potongan

\begin{tabular}{|c|c|c|c|c|c|c|c|c|c|c|c|}
\hline & TR & DB & MT & JT & $\mathrm{BK}$ & LD & AP & PM & GM & GI & SB \\
\hline $\mathrm{DB}$ & 0.04 & & & & & & & & & & \\
\hline MT & -0.13 & 0.22 & & & & & & & & & \\
\hline JT & 0.32 & -0.16 & -0.29 & & & & & & & & \\
\hline $\mathrm{BK}$ & 0.25 & $0.49 * *$ & 0.30 & -0.08 & & & & & & & \\
\hline LD & 0.03 & -0.19 & $-0.32 *$ & 0.27 & -0.29 & & & & & & \\
\hline AP & 0.16 & 0.27 & 0.03 & -0.07 & 0.10 & $-0.41 * *$ & & & & & \\
\hline PM & 0.27 & $0.43 * *$ & 0.06 & 0.20 & 0.19 & $0.30 *$ & -0.24 & & & & \\
\hline GM & $0.41 * *$ & 0.21 & -0.06 & 0.28 & 0.11 & $0.33 * *$ & -0.24 & $0.86^{* *}$ & & & \\
\hline GI & 0.09 & 0.07 & -0.09 & -0.26 & 0.02 & $-0.36 * *$ & -0.15 & 0.24 & $0.31 * *$ & & \\
\hline SB & -0.33 & $-0.32 *$ & -0.17 & -0.04 & $-0.51 * *$ & 0.23 & -0.14 & -0.04 & -0.06 & 0.01 & \\
\hline GKG & 0.23 & -0.25 & -0.06 & 0.12 & -0.01 & -0.09 & $0.31^{*}$ & $0.69 * *$ & $0.48 * *$ & 0.24 & 0.24 \\
\hline
\end{tabular}

Keterangan: - = korelasi negatif; $*$ = korelasi nyata; $* *=$ korelasi sangat nyata; $\mathrm{TR}=$ tinggi ratun; $\mathrm{DB}=$ diameter batang; $\mathrm{LD}=$ luas daun; $\mathrm{MT}=$ waktu muncul tunas; $\mathrm{JT}=$ jumlah tunas; $\mathrm{BK}=$ posisi tunas pertama; $\mathrm{AP}=$ anakan produktif; $\mathrm{PM}=$ panjang malai; $\mathrm{GM}=$ jumlah gabah/malai; $\mathrm{GI}=$ jumlah gabah isi; $\mathrm{SB}=$ bobot 1,000 butir; $\mathrm{GKG}=$ gabah kering giling 


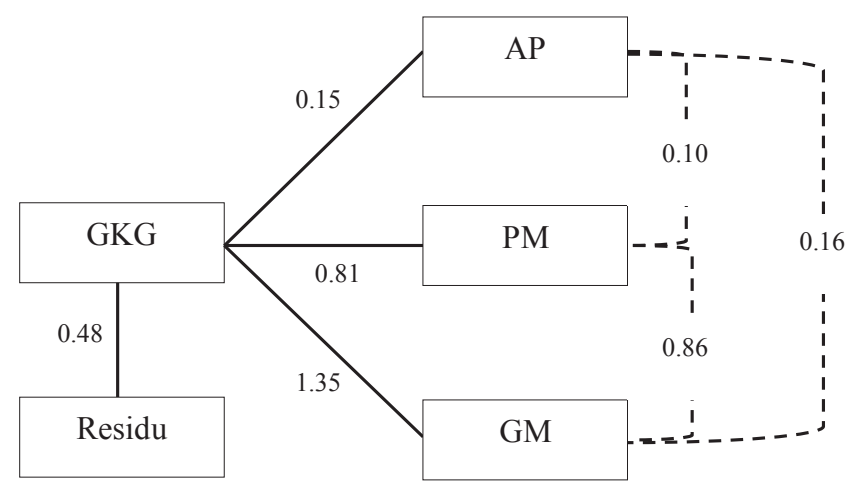

- - pengaruh langsung; --- = pengaruh tidak langsung; AP = anakan produktif; $\mathrm{PM}=$ panjang malai; $\mathrm{GM}=$ jumlah gabah per malai; $\mathrm{GKG}=$ gabah kering giling

Gambar 2. Sidik lintas komponen hasil terhadap hasil ratun beberapa varietas padi dengan perlakuan tinggi potongan

\section{KESIMPULAN}

Potongan setinggi $20 \mathrm{~cm}$ menghasilkan anakan ratun terbanyak pada IPB 3S dan Inpago 9. Inpara 8 unggul dalam menghasilkan anakan produktif yang berkorelasi dengan hasil gabah kering giling. Kelompok padi sawah (IPB 3S) dengan ketinggian $30 \mathrm{~cm}$ dan padi rawa (Inpara 8) dengan ketinggian $20 \mathrm{~cm}$ dapat menghasilkan ratun yang baik berdasarkan kemampuannya menghasilkan GKG ratun. Berdasarkan hasil sidik lintas, jumlah gabah per malai memberikan pengaruh langsung terhadap hasil ratun.

\section{DAFTAR PUSTAKA}

Alizadeh, M.R., F.R. Ajdadi, A. Dabbaghi. 2011. Cutting energy of rice stem as influenced by internodes position and dimensional characteristics of different varieties. AJCS. 5:681-687.

Ambarita, Y., D. Hariyono, N. Aini. 2017. Aplikasi pupuk NPK dan urea pada padi (Oryza sativa L.) sistem ratun. J. Protan. 5:1228-1234.

Azizi, P., M.Y. Rafil. M. Maziah, S.N.A. Abdullah, M.M. Hanafi, M.A. Latif, A.A. Rashid, M. Sahebi. 2015. Understanding the shoot apical meristem regulation: a study of the phytohormones, auxin and cytokinin in rice. Mech. Dev. 1335:1-15.

Bakhtiar, B.S. Purwoko, Trikoesoemaningtyas, I.S. Dewi. 2010. Analisis korelasi dan koeisien lintas antar beberapa sifat padi gogo pada media tanah masam. J. Floratek. 5:86-93.

[BBPTP] Balai Besar Penelitian Tanaman Padi. 2017. Teknik Ubinan: Pendugaan Produktivitas Padi Menurut Sistem Tanam. BBPTP, Subang, ID.
Bond, J.A., P.K. Bolich. 2006. Effects of pre-harvest deciccants on rice yield and quality. Crop Protec. 26:490-494.

Chen, Q., A. He, W. Wang, S. Peng, J. Huang, K. Cui, L. Nie. 2018. Comparrison of regeneration rate and yields performance between inbred and hybrid rice cultivars in direct seeding rice ratoon system in central China. Field Crops Res. 223:164-170.

Dariah, A., N. Heryani. 2014. Pemberdayaan lahan kering suboptimal untuk mendukung kebijakan diversifikasi dan ketahanan pangan. J. Sumberdaya Lahan 8:1-16.

De Datta, S.K., Bernasor. 1988. Agronomic principles and practices of rice ratooning. In W.H. Smith, V. Kumble, E.P. Cervantes (Eds.). Rice Ratooning. IRRI, Los Banos, PH.

Dong, H., Q. Chen, W. Wang,S. Peng, J. Huang, K. Cui, L. Nie. 2017. The growth and yield of a wet- seeded rice-ratoon rice system in central China. Field Crops Res. 208:55-59.

Faruq, G., R.M. Taha, Z.H. Prodhan. 2014. Rice ratoon crop: a sustainable rice production system for tropical hill agriculture. Sustainability 6:5785-5800.

Harrel, D.L., A.B. Jason, B. Sterling. 2009. Evaluation of main-crop stubble height on ratoon rice growth and development. Field Crops Res. 114:396-403.

He, X., Y. Qiao, L. Liang, M.T. Knudsed, F. Martin. 2018. Environmental life cycle assessment of long-term organic rice production in subtropical China. J. Clean Prod. 176:880-888.

He, A., W. Wang, G. Jiang, H. Sun, M. Jiang, J. Man, K. Cui, J. Huang, S. Peng, L. Nie. 2019. Source-sink regulation and its effects on the regeneration ability of ratoon rice. Field Crops Res. 236:155-164.

Islam, M.S., M. Hasannuzzaman, M. Rukonuzzaman. 2008. Ratoon rice response to different fertilizer doses in irrigated condition. Agric. Conspec. Sci. 73:197202.

Jahari, M., P.H. Sinaga. 2019. Menyiasati penyempitan musim tanam padi dengan budidaya ratun dan salibu. J. Dinamika Pertanian 3:67-72.

Khuluq, A.F., R. Hamida. 2014. Peningkatan produktivitas dan rendemen tebu melalui rekayasa fisiologis pertunasan. Perspektif 13:13-24.

Lin, W.X. 2019. Developmental status and problems of rice ratoning. J. Integr. Agric. 18:240-247. 
Liu, H., S. Hussain, M. Zheng, L. Sun, S. Fahad, J. Huang, L. Nie. 2014. Progress and constraints of dry directseeded rice in China. J. Food Afric. Environ. 12:465472.

Mapegau, A. Paiman, Marlina. 2018. Karakter agronomi padi ratun [Oryza sativa (L.)] varietas lokal pasang surut Tanjung Jabung Timur. Agroecotania 1:26212846.

Mareza, E., Z.R. Djafar, R.A. Suwignyo, A. Wijaya. 2016. Morfofisiologi ratun padi sistem tanam benih langsung di lahan pasang surut. J. Agron. Indonesia 44:228-234.

Meliala, G.M., Trikoesoemaningtyas, D. Sopandie. 2017. Keragaan dan kemampuan meratun lima genotipe sorgum. J. Agron. Indonesia 45:154-161.

Ningrum, M.F.S., W.M. Indriatama, H. Gustia. 2018. Produktivitas ratun pertama 45 galur mutan sorgum. hal. 32-40. Dalam F. Nurlidar, R. Prasetio, A. Citraresmini (Eds.). Prosiding Seminar Nasional APISORA. Jakarta 9 Agustus 2018.

Nuzul, V.S., D. Indradewa, D. Kastono. 2018. Pengaruh waktu dan tinggi pemotongan tunggul terhadap komponen hasil dan hasil padi (Oryza sativa L.) ratun. Vegetalika 7:54-65.

Rachmawati, R.S., Kuswanto, S.L. Purnamaningsih. 2014. Uji keseragaman dan analisis sidik lintas antara karakter agronomis dengan hasil padi tujuh genotip padi hibrida japonica. J. Protan. 2:292-300.

Ruminta. 2016. Analisis penurunan produksi tanaman padi akibat perubahan iklim di Kabupaten Bandung Jawa Barat. J. Kultivasi 15:37-45.
Sadeghi, S.M. 2011. Heritability, phenotypic correlation and path coefficient studies for some agronomic characters in landrace rice varieties. World Appl. Sci. J. 13:1229-1233.

Sinaga, P.H., Trikoesoemaningtyas, D. Sopandie, H. widinnoor. 2015. Daya hasil dan stabilitas ratun galur padi pada lahan pasang surut. Penelitian Pertanian Tanaman Pangan 32:97-104.

Susilawati, B.S. Purwoko, H. Aswidinnoor, E. Santosa. 2010. Keragaan varietas dan galur padi tipe baru Indonesia dalam sistem ratun. J. Agron. Indonesia 38:177-184.

Susilawati. 2011. Agronomi ratun genotipe-genotipe padi potensial untuk lahan pasang surut. Disertasi. Sekolah Pascasarjana. Institut Pertanian Bogor. Bogor.

Susilawati, B.S. Purwoko, H. Aswidinnoor, E. Santosa. 2012. Tingkat produksi ratun berdasarkan tinggi potongan batang padi sawah saat panen. J. Agron. Indonesia 40:1-7.

Vinutha, K.S., G.S.A. Kumar, B. Michael, P.R. Rao. 2016. Evaluation of yield and forage quality in main and ratoon crops of different sorghum lines. Trop. Grassl. Forrajes. Trop. 5:40-49.

Wang, W., A. He, G. Jiang, H. Sun, M. Jiang, J. Man, X. Ling, K. Cui, J, Huang, S. Peng, L. Nie. 2020. Ratoon rice technology: a green and resource-efficient way of rice production. Adv. in Agronomy 159:136-161.

Xu, F., H. Xiong, L. Zhang, Y. Zhu, P. Jiang, X. Guo, M. Liu. 2015. Progress in research of yield formation of ratooning rice and its high-yielding key regulation technologies. Sci. Agric. Sin. 48:1702-1717. 